\title{
Final Report for High Precision Short-Pulse Laser Ablation System for Medical Applications
}

\author{
B.-M. Kim, M. D. Feit, A. M. Rubenchik, J. E. Marion
}

\section{March 4, 2000}




\section{DISCLAIMER}

This document was prepared as an account of work sponsored by an agency of the United States Government. Neither the United States Government nor the University of California nor any of their employees, makes any warranty, express or implied, or assumes any legal liability or responsibility for the accuracy, completeness, or usefulness of any information, apparatus, product, or process disclosed, or represents that its use would not infringe privately owned rights. Reference herein to any specific commercial product, process, or service by trade name, trademark, manufacturer, or otherwise, does not necessarily constitute or imply its endorsement, recommendation, or favoring by the United States Government or the University of California. The views and opinions of authors expressed herein do not necessarily state or reflect those of the United States Government or the University of California, and shall not be used for advertising or product endorsement purposes.

Work performed under the auspices of the U. S. Department of Energy by the University of California Lawrence Livermore National Laboratory under Contract W-7405-Eng-48.

This report has been reproduced

directly from the best available copy.

Available to DOE and DOE contractors from the

Office of Scientific and Technical Information

P.O. Box 62, Oak Ridge, TN 37831

Prices available from (423) 576-8401

http://apollo.osti.gov/bridge/

Available to the public from the

National Technical Information Service

U.S. Department of Commerce

5285 Port Royal Rd.,

Springfield, VA 22161

http://www.ntis.gov/

OR

Lawrence Livermore National Laboratory

Technical Information Department's Digital Library

http://www.llnl.gov/tid/Library.html 


\section{Final report for \\ High Precision Short-Pulse Laser Ablation System for Medical Applications}

Tracking Number : 97-LW-074

Investigators

Beop-Min Kim (PI, Laser Programs)

Michael D. Feit (Laser Programs)

Alexander M. Rubenchik (UC/DAS)

John E. Marion (Laser Programs) 


\section{SUMMARY}

During the three year LDRD funding period, we studied the ablation characteristics of biological tissues using ultrashort pulse lasers (USPL) with pulse widths varying from 100 femtoseconds to tens of picoseconds. During the first year, we performed extensive theoretical studies to develop an improved understanding of the USPL ablation process. Two optical signals were tested for feasibility of use in real-time feedback systems during high repetition rate ablation. In the second year, we devised a real-time, feedbackcontrolled USPL ablation system, based on luminescence, which may be useful for sensitive micro-spinal surgeries. Effective laser parameters were identified to reduce collateral damage. The final year of the project focused on quantification of the pressure pulse induced by USPL ablation of water surfaces representing biological tissues. Results of these studies were presented in invited talks at domestic and international conferences and numerous journal articles were published (see bibliography). This effort has increased our scientific understanding of physical processes important for the therapeutic biomedical application of ultrashort pulse lasers, and has taken the first steps toward practical realization of such applications.

\section{Year 1}

Commercially available ultrashort laser pulses (USLP) are intense enough to cause optical breakdown and plasma formation (hot ionized vapor) via direct multiphoton absorption in insulators. Since the nonlinear absorption is an order of magnitude higher than the linear absorption due to chromophores, most of the pulse energy is concentrated in a thin surface region $(100-200 \mathrm{~nm})$. The high energy density accumulation in a thin superficial layer results in high local pressure $(\sim 1 \mathrm{Mbar})$ and temperature $(\sim \mathrm{few} \mathrm{eV})$ which are quickly released by rapid plasma expansion and shockwaves $[1,2,3,4]$. Due to this fast ejection of the plasma, the energy transfer to the lattice of the material is minimized leaving virtually no collateral damage to the surrounding area. That is, the shockwave has high initial pressure which rapidly disperses which propagation into the material. One dimensional modeling studies revealed that the peak pressure during the pulse can be as large as $1 \mathrm{Mbar}$ and the corresponding temperature rise can reach up to 20 $\mathrm{eV}\left(1 \mathrm{eV}=11600^{\circ} \mathrm{K}\right)$ with input laser energy fluence of $1.5 \mathrm{~J} / \mathrm{cm}^{2}$ and $500 \mathrm{fs}$ pulse duration. The high pressure reduces to several kbar after penetrating only tens of microns. Compared to ablation caused by nanosecond pulses, significant temperature rise is limited to the near surface area.

Experiments showed that the ablation rate in dentin is approximately $1 \mu \mathrm{m} /$ pulse which corresponds to removal of $1 \mathrm{~mm} / \mathrm{sec}$ using a $1 \mathrm{kHz}$ repetition rate system. Scanning electron microscopy (SEM) studies verified lack of collateral damage at the ablation craters $[5,6,7,8]$. 


\section{Year 2}

Knowing that short pulse lasers can effectively remove material while leaving minimal collateral damage, we devised a feedback controlled ablation system to eliminate possible damage to adjacent sensitive tissues. During the first year, preliminary work focused on discrimination between calcium based hard tissues and carbon based soft tissues using either fluorescence or plasma luminescence [9]. This feedback technique is targeted for application to micro-spinal surgery in which there is a need to remove bone tissue without harming nerve tissues. Our studies showed that luminescence spectroscopy is superior for discrimination of bone and nerve tissues. A computer-controlled feedback system utilized the high intensity luminescence of calcium at $616 \mathrm{~nm}$ and it was used in selective ablation of the bone tissues successfully [10].

Ablation thresholds were measured for hard dental tissues (dentin) and water and it was found that the threshold increases at longer pulse widths $[6,11]$. It was found that the threshold increased as the square root of pulse width for pulses longer than several picoseconds. The square root pulselength dependence is expected theoretically for a thermal ablation process and has been found experimentally for various materials at longer pulsewidths. The threshold found in our studies deviates from the traditional thermal ablation dependence on pulsewidth for pulses of duration of several picoseconds and lower. SEM pictures of the ablation craters generated using $100 \mathrm{fs}, 1$ ps, 5 ps, and 10 ps pulses were examined. It was found that crater morphology changes at pulse widths between 1 ps and 5 ps. Evidence of melting and thermal damage was observed at the walls and edges of the 5 ps and 10 ps craters. A separate experiment, using water, confirmed the transition of ablation characteristics in the range of $1 \mathrm{ps}-5 \mathrm{ps}$ [11]. It was found that a significant amount of energy of 5 ps or longer pulses penetrates through the plasma layer and is volumetrically absorbed along the beam axis. This indicates extensive thermal damage might be introduced into the deeper region by longer pulses. The water experiment was performed during the third year. As a result of these independent studies, it was concluded that 1 ps pulses created ablation characteristics similar to those of $100 \mathrm{fs}$ pulses. This is an important finding since it is likely that the device cost will be much less for manufacturing $1 \mathrm{ps}$ lasers instead of $100 \mathrm{fs}$ lasers. Additionally, 1 ps pulses are expected to be deliverable using optical fibers which is not possible for $100 \mathrm{fs}$ pulses due to strong group velocity dispersion and optical fiber damage problems.

Interestingly enough, it was found that larger incident USLP energy does not guarantee faster ablation. We tested the ablation rate with intensities of $2 \mathrm{x}, 4 \mathrm{x}$, and $7 \mathrm{x}$ observed ablation thresholds. The results showed that the ablation rate was approximately 1 $\mu \mathrm{m} /$ pulse for all cases as long as the ablation front moves deeper into the tissues. On the other hand, thermal or mechanical damage was observed at the ablation crater generated using $4 \mathrm{x}$ and $7 \mathrm{x}$ threshold energies. It appears that the $2 \mathrm{x}$ ablation threshold might be an 
optimal pulse intensity as regards energy efficiency and minimal collateral damage. This result was presented in international conferences and a journal publication is in preparation.

The ablation threshold of USLP was measured as a function of various parameters [12]. It was found that the threshold decreases with high repetition rate, larger beam size, and more pulses, all indicative of importance of thermal processes during ablation. Therefore, high repetition rate USLP ablation may result in some thermal damage if these parameters are not set appropriately. However, it is desirable to have a high repetition rate and large beam size to improve the volume ablation rate. With current commercial USPL systems, the largest pulse output energy is $\sim 1 \mathrm{~mJ}$ with a repetition rate of $1 \mathrm{kHz}$. The maximum beam diameter at which $2 \mathrm{x}$ threshold intensity can be reached is thus $280 \mu \mathrm{m}$. Therefore, the ablation rate can be up to $0.063 \mathrm{~mm}^{3} / \mathrm{sec}$ which means that it takes 16 seconds to ablate $1 \mathrm{~mm}^{3}$. Increasing the repetition rate to $10 \mathrm{kHz}$ improves the ablation rate to $0.63 \mathrm{~mm}^{3}$ which is comparable to other tissue removal tools. However, as shown above, higher repetition rate can result in thermal damage. Therefore, it is suggested that a fast beam scanning system might be needed to avoid continuously ablating at a single position and causing thermal damage.

\section{Year 3}

During the final year of the project, the focus was on measurement of pressure induced in water by USLP ablation. Purified water was used as a tissue model. A Mach-Zehnder interferometer was devised to directly quantify the density change and thus the pressure of spherical waves generated at the water surface ablation center. The induced pressure was calculated from the phase shift observed in the interferograms [13]. The pressure immediately after the irradiation could not be measured since the phase shift was not obviously discernable. Pressure of spherical shock waves after traveling $50-500 \mu \mathrm{m}$ from the ablation center was measured for the pulse width range of $100 \mathrm{fs}-1 \mathrm{ps}$. It was found that the pressure is dependent on the multiples of threshold at each pulse width rather than the pulse energy. The pressure decays inversely with distance which is indicative of a weak shock or normal acoustic wave. By integrating pressure over the acoustic waves, the total wave energy was calculated. It was found that the rate of laser energy conversion to pressure was less than $1 \%$. This finding was confirmed by computer simulation of the USLP-induced pressure waves which also predicted that the energy conversion is lower than $1 \%$. These pressure studies indicate a much lower energy conversion rate during USLP ablation than that due to long pulsewidth ablation, consistent with the lower observed mechanical damage.

During the three year grant period, we improved our understanding of the USLP ablation process in biological tissues which certainly indicates that USLP technique has potential to be used for high-precision ablation of biomedical materials with low 
collateral damage. We proposed optimal laser parameters for safe and effective tissue ablation. The USLP market is currently driven by micromachining industries. With recent marked success in USLP technologies, it is expected that compact, affordable USLP ablation systems will be available for medical applications in the near future. A list of potential medical applications that might be benefited by USLP technology was presented in ref. [14] 


\section{PUBLICATIONS LIST}

1. M. D. Feit, A. M. Rubenchik, B. -M. Kim, L. B. Da Silva, and M. D. Perry, "Physical characterization of ultrashort laser pulse drilling of biological tissue," Applied Surface Science, 127-129, pp. 869-874, 1998 (UCRL-JC-127269)

2. A. M. Rubenchik, M. D. Feit, M. D. Perry, and J. T. Larsen, "Numerical simulation of ultra-short laser pulse energy deposition and bulk transport for material processing," Applied Surface Science, 127-129, pp. 193-198, 1998 (UCRL-JC-127279)

3. B.-M. Kim, M. D. Feit, A. M. Rubenchik, D. M. Gold, B. C. Stuart, and L. B. Da Silva, "Ultrashort pulse laser ablation of biological tissues," SPIE Proceedings, $\mathbf{3 2 5 4}$, pp. 203-210, 1998 (UCRL-JC-130595)

4. A. M. Komashko, M. D. Feit, A. M. Rubenchik, M. D. Perry, and P. S. Banks, "Simulation of material removal efficiency with ultrashort laser pulses," Applied Physics A, 69, pp. S95-S98, 1999 (UCRL-JC-133744)

5. M. D. Feit, B. C. Stuart, A. M. Rubenchik, M. D. Perry, L. B. Da Silva, and J. Neev, "Ultrashort laser pulse ablation of hard tissue," OSA Trends in Optics and Photonics, 17, p. 173, 1998 (UCRL-JC-129002)

6. M. D. Perry, B. C. Stuart, P. S. Banks, M. D. Feit, V. Yanovsky, and A. M. Rubenchik, "Ultrashort-pulse laser machining of dielectric materials," Journal of Applied Physics, 85, pp. 6803-6810, 1999 (UCRL-JC-132156)

7. B. C. Stuart, M. D. Perry, M. D. Feit, L. B. Da Silva, A. M. Rubenchik, J. Neev, "Machining of biological materials, dielectrics and metals with femtosecond lasers," OSA Trends in Optics and Photonics : Lasers and Optics for manufacturing, 9, pp. 9498, 1997 (UCRL-JC-125735)

8. M. D. Feit, B. C. Stuart, L. B. Da Silva, M. D. Perry, A. M. Rubenchik, J. Neev, "Ultrashort Laser Pulse Ablation of Hard Tissue," OSA Trends in Optics and Photonics, 17, pp. 173-83, 1998 (UCRL-JC-129002)

9. B.-M. Kim, M. D. Feit, A. M. Rubenchik, B. M. Mammini, and L. B. Da Silva, "Optical feedback signal for ultrashort laser pulse ablation of tissue," Applied Surface Science, 127-129, pp. 857-862, 1998 (UCRL-JC-128614)

10. B.-M. Kim, M. D. Feit, A. M. Rubenchik, D. M. Gold, C. B. Darrow, J. E. Marion, and L. B. Da Silva, "Plasma luminescence feedback control system for precise ultrashort pulse laser tissue ablation," SPIE Proceedings, 3255, pp. 92-97, 1998 (UCRL-JC-130596)

11. B.-M. Kim, M. D. Feit, A. M. Rubenchik, E. J. Joslin, P. M. Celliers, J. Eichler and L. B. Da Silva, "Influence of pulse duration on ultrashort laser pulse ablation of biological tissues," Journal of Biomedical Optics, (submitted) (UCRL-JC-136332)

12. B.-M. Kim, M. D. Feit, A. M. Rubenchik, E. J. Joslin, J. Eichler, P. C. Stoller and L. B. Da Silva, "Effects of high repetition rate and beam size on hard tissue damage due 
to sub-picosecond laser pulses," Applied Physics Letters, (submitted) (UCRL-JC135926)

13. B.-M. Kim, M. D. Feit, A. M. Rubenchik, A. M. Komashko, J. Eichler, S Reidt, P. M. Celliers, and L. B. Da Silva, "Pressure induced during water ablation by USLP," Viewgraphs presented in SPIE'2000, San Jose, CA, January 22-28, 2000 (UCRL-VG137260)

14. J. E. Marion, and B.-M. Kim, "Medical applications of ultra-short pulse lasers," SPIE Proceedings, 3616, pp. 42-50, 1999 (UCRL-JC-133470-REV-1) 